\title{
Prevalence of hepatitis A virus infection: the paradoxical example of isolated communities in the western Brazilian Amazon region
}

\section{Prevalência da infecção pelo vírus da hepatite A: o exemplo paradoxal de comunidades isoladas na região Amazônica Ocidental Brasileira}

\author{
Wornei Silva Miranda Braga ${ }^{1}$, Fabiane Giovanella Borges ${ }^{1}$, Gildo Maia Barros Júnior ${ }^{1}$, \\ Ana Cristina de Souza Martinho ${ }^{1}$, Ivo Seixas Rodrigues ${ }^{1}$, Eliete Pereira de Azevedo ${ }^{1}$, \\ Gustavo Henrique Nolasco Grimmer Davis ${ }^{3}$, Manoel Bezerra de Queiroz ${ }^{4}$, \\ Simone Helena Derzi dos Santos ${ }^{5}$, Thiago Vitoriano Barbosa ${ }^{5}$ \\ and Márcia da Costa Castilho ${ }^{1,2}$
}

\begin{abstract}
This study evaluated the prevalence of hepatitis A virus infection in the rural area of Lábrea, in the western Brazilian Amazon region. Communities and households were selected randomly. Serum samples were analyzed by means of the immunoenzymatic method for the presence of total antibodies against HAV. The study included 1,499 individuals. The prevalence of anti-HAV was 74.6\% (95\% CI 72.3-76.8). Univariate analysis showed associations with age (chi-square for linear trend $=496.003, \mathrm{p}<0.001)$, presence of outside toilet $(\mathrm{p}<0.001)$, history of hepatitis $(\mathrm{p}<0.001)$ and family history of hepatitis $(\mathrm{p}=0.05)$. After adjusting for age, HAV infection also showed an association with the number of people in the family $(\mathrm{p}=0.03)$. The overall prevalence rates were high, but not more than $60 \%$ of the children under the age of ten years had already been infected. Very high prevalence was detected only within older cohorts, thus paradoxically defining this as a region with intermediate endemicity, even under the conditions of poverty encountered.
\end{abstract}

Key-words: Hepatitis A virus. Epidemiology. Prevalence. Amazon region. Brazil.

\section{RESUMO}

Este estudo avaliou a prevalência de infecção pelo vírus da hepatite A na área rural de Lábrea, Amazônia Ocidental Brasileira. Comunidades e domicílios foram selecionados aleatoriamente. Amostras de soro foram analisadas pelo método imunoenzimático para os anticorpos totais contra o vírus da hepatite A. O estudo incluiu 1.499 indivíduos. A prevalência do anti-HAV foi 74,6\% (IC 95\% 72,3 a 76,8). Análise univariada mostrou associação com idade (qui-quadrado de tendência linear $=496,003, \mathrm{p}<0,001)$, presença de sanitário fora do domicílio $(\mathrm{p}<0,001)$, passado de hepatite $(\mathrm{p}<0,001)$ e história familiar de hepatite $(\mathrm{p}=0,05)$. Depois de controlado por idade, a infecção pelo VHA mostrou também associação com o número de pessoas na família $(\mathrm{p}=0,03)$. A prevalência global mostra taxas elevadas, entretanto não mais do que $60 \%$ dos menores de 10 anos, já são infectados, e prevalências elevadas são detectadas em coortes de mais idade, mostrando paradoxalmente uma definição de região de endemicidade intermediária, mesmo nas condições de pobreza encontradas.

Palavras-chaves: Vírus da hepatite A. Epidemiologia. Prevalência. Região amazônica. Brasil.

1. Virology Unit, Tropical Medicine Foundation of Amazonas, Manaus, AM. Brazil. 2. Amazonas State University, Manaus, AM. Brazil 3. Leônidas and Maria Deane Research Center, Oswaldo Cruz Foundation (Fiocruz), Manaus, AM. Brazil 4. Municipality of Labrea Health Department, Lábrea, AM. Brazil 5. Amazonas Federal University, Manaus, AM. Brazil.

Financial support: This study was funded by the Amazonas State Foundation for Support of Scientific Research (FAPEAM).

Address to: Dr. Wornei Silva Miranda Braga. Gerência de Virologia/FMT-AM. Av. Pedro Teixeira 25, 69040-000 Manaus, AM, Brazil.

Telefax: 5592 3238-3762

e-mail: wornei.braga@hotmail.com; wbraga@fmt.am.gov.br

Received in 26/11/2008

Accepted in 22/05/2009
Hepatitis A virus (HAV) distribution is associated with poor economic development, sanitation, environmental conditions and personal hygiene ${ }^{911} 19$. Three epidemiological patterns have been described according to the prevalence of past infection, as measured by the presence of total antibodies against HAV (anti$\mathrm{HAV})$. These patterns of prevalence are used because it is very difficult to estimate the incidence of this disease, due to the great number of asymptomatic cases, and because total anti-HAV is believed to be an immune marker that persists for years ${ }^{25}$.

In areas of low endemicity, the overall prevalence is around $25 \%$, outbreaks from a common source are very frequent, risk 
groups can be defined and severe clinical cases are describe within old cohorts with an increased case fatality rate of $2 \%{ }^{19}$.

Areas of high endemicity have been described in developing and poor regions in which more than $90 \%$ of the population up to the age of 10 is already infected and the majority of the cases are asymptomatic ${ }^{12}$.

Intermediate prevalence is said to be a transition stage between the high and low epidemiological patterns ${ }^{9}$. High prevalence rates of more than $90 \%$ can also be found mainly among young adults and adolescents, but in this situation, the rate of clinical disease may be higher and occurrences of severe clinical cases are very common $^{19}$.

In Brazil, HAV infection accounts for the majority of viral hepatitis notifications ${ }^{24}$. Changes in the epidemiological patterns have been described in some regions due to improvements in sanitation and socioeconomic conditions ${ }^{1022}$. Nevertheless, all three patterns can be identified, even within a particular geographical region ${ }^{724}$.

The present study had the aim of determining the prevalence of previous HAV infection among the populations of rural villages in the Purus river basin, within the municipality of Lábrea, in the western Brazilian Amazon region.

\section{MATERIAL AND METHODS}

The target population comprised the inhabitants of rural villages in the Purus river basin, within the municipality of Lábrea, in the western Brazilian Amazon region (Figure 1). Fifty-five villages were visited between March 2005 and April 2006, for data collection.

The study population was very homogeneous regarding living and environmental conditions. The villages are located along the banks of the Purus River. This area is flooded for half of the year and has very rich soil that is used for agriculture during the dry season. The villages are mostly inhabited by the families of former workers in the natural rubber plantations.

It is difficult to establish any social or economic differences, since all of the families seem to live at the same level of poverty and lack of environmental sanitation. Half of the population is illiterate. People earn money from selling of forest products, fish, beans and corn, and the income of the whole community in a village of one hundred inhabitants is no more than US\$5,000 per year.

Nonetheless, very recently, we have noticed some improvements in terms of social programs settling people on the land. Most of the villages have a teacher living in the community. Rural properties have been transformed into natural reserves for sustainable management of natural resources, such as husbandry of wild animals like river turtles and some birds, gathering of forest products and exploitation of natural rubber.

This was a population-based cross-sectional survey. The sample size was estimated using the official rural area census population ${ }^{13}$ and the estimated prevalence of antibodies against

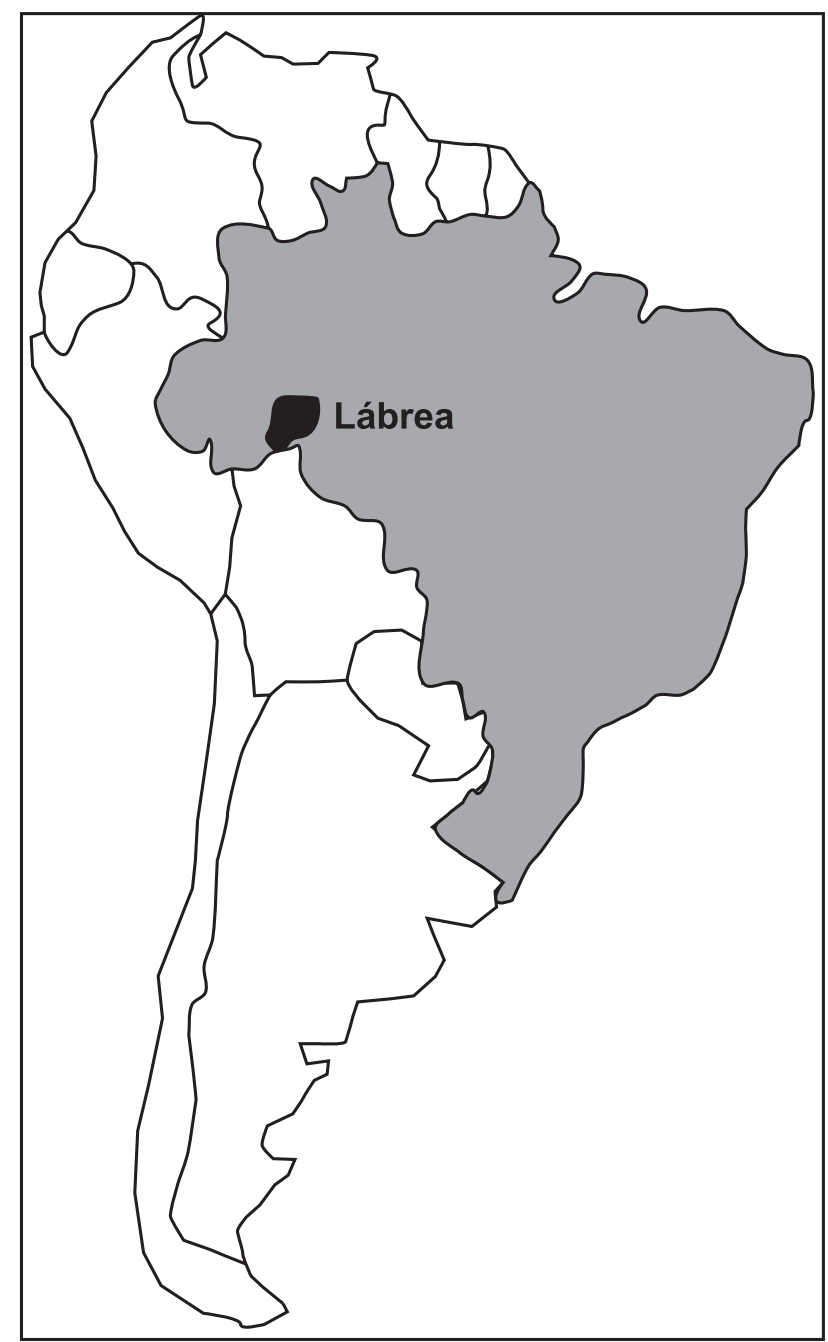

FIGURE 1

Map of the study area.

hepatitis C virus (anti-HCV) in the general population ${ }^{21}$, since this study was also designed to evaluate the prevalence of serological markers for hepatitis B, C and D. Since the prevalence of anti-HCV is believed to be lower than that of the other types of hepatitis, the estimated sample size needed to be large enough to measure the prevalences of $\mathrm{HAV}$, hepatitis B virus (HBV), hepatitis $\mathrm{C}$ virus (HCV) and hepatitis delta virus (HDV). For sample calculation, we also used a design factor of 2 , precision of $\pm 3 \%$ and $95 \%$ confidence level. These parameters yield a minimum sample of 1,287 individuals.

The villages were randomly selected from a list from the malaria control program, thus ensuring that we covered the whole geographical area of the municipality. Households were randomly selected after the research team arrived. In small villages of up to ten households, all the families were investigated. After subjects had given their written consent to their participation in the study, individual questionnaires were filled out and blood samples of $10 \mathrm{ml}$ each were taken from those present at the time of the investigation.

This study had previously been reviewed and approved by the Ethics Review Board of the Tropical Medicine Foundation of Amazonas (FMTAM), Manaus, Amazonas, Brazil. 
Serum samples were analyzed by means of the enzyme-linked immunosorbent assay (ELISA) to test for total anti-HAV, using a commercial kit (DiaSorin, S.p.A., Saluggia, Italy). The test procedures followed the manufacturer's recommendations and were performed at the Virology Unit of FMTAM.

The anti-HAV prevalence and corresponding $95 \%$ confidence intervals $(95 \% \mathrm{CI})$ were estimated in relation to the study variables of interest, such as gender, age group, water source, existence of treated drinking water, number of people per household, presence of outside toilet, parents' education level, history of clinical hepatitis and family history of hepatitis, among others. The chi-square test was used to compare proportions. Since age is positively associated with anti-HAV prevalence and is considered to be an important potential confounder, all statistical associations that were detected were controlled for using stratification by age group. Differences were considered significant with $\mathrm{p} \leq 0.05$. The population was stratified by year for the first four years of life, and then by five-year increments up to the age of 19 and, finally, individuals aged 20 and over. Epi Info version 3.3.2 $2^{6}$ was used for statistical data management and analysis.

\section{RESULTS}

This study was conducted on a population of 298 families, totaling 1,499 individuals. The overall prevalence rate for total antiHAV was $74.6 \%$ (95\% CI 72.3-76.8). There was a heterogeneous pattern regarding the distribution between villages, ranging from 47.5\% (29/61) in the village of "Amparo" (07³8'31.3"s; $\left.65^{\circ} 28^{\prime} 25.3^{\prime \prime} \mathrm{W}\right)$ to as high as $97.6 \%(40 / 41)$ in the village of "Praia do Gado" (07¹6'52.8”s; 6450'12.6”W).

Only one third of the subjects had already been infected by the age of five, and the proportion of immune subjects among the general population only reached $95 \%$ at the age of 20 and over. The age distribution of the study population is shown in Figure 2.

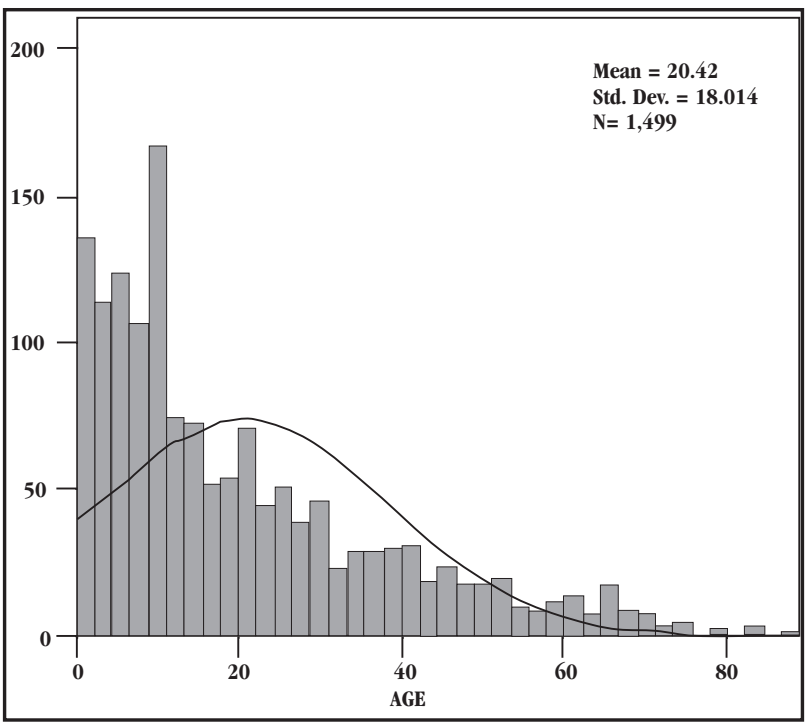

FIGURE 2

Age distribution of study population.
Univariate analysis showed that there was a statistical association with increasing age (chi-square for linear trend $=$ $496,003, p<0.001)$. Positive individuals were much older than the negative ones, with median ages of 20 and 5 years, respectively (Kruskal-Wallis test $=432,522, p<0.001)$ (Table 1).

\section{TABLE 1}

Prevalence of total anti-HAV and distribution of associated risk factors among the rural population of the Purus River basin, municipality of Lábrea, State of Amazonas, Brazil.

\begin{tabular}{|c|c|c|c|c|c|}
\hline Variable & Number & Number + & Anti-HAV IgG (\%) & $95 \% \mathrm{CI}$ & $p$-value \\
\hline Total sample & 1,499 & 1,118 & 74.6 & $72.3-76.8$ & \\
\hline \multicolumn{6}{|l|}{ Age group } \\
\hline $1 y$ & 65 & 21 & 32.3 & $30.3-34.3$ & \\
\hline $2 y$ & 71 & 9 & 12.7 & $10.5-14.9$ & \\
\hline $3 y$ & 47 & 16 & 34.0 & $31.7-36.3$ & \\
\hline $4 y$ & 67 & 23 & 34.3 & $32.4-36.2$ & $<0.0001^{*}$ \\
\hline $5-9$ & 296 & 178 & 60.1 & $59.4-60.8$ & \\
\hline $10-14$ & 215 & 174 & 80.9 & $80.3-81.5$ & \\
\hline $15-19$ & 140 & 125 & 89.3 & $88.8-89.8$ & \\
\hline$\geq 20$ & 598 & 572 & 95.7 & $95.5-95.9$ & \\
\hline \multicolumn{6}{|l|}{ Gender } \\
\hline male & 768 & 573 & 74.6 & $74.2-74.9$ & 0.51 \\
\hline female & 731 & 545 & 74.6 & $74.2-74.9$ & \\
\hline \multicolumn{6}{|l|}{ Water source } \\
\hline river & 1,388 & 1,041 & 75.0 & $74.7-75.3$ & 0.11 \\
\hline others*** & 111 & 77 & 69.4 & 68.4-70.4 & \\
\hline $\begin{array}{l}\text { Treated drink } \\
\text { water }\end{array}$ & & & & & \\
\hline yes & 1,111 & 833 & 75.0 & $74.7-75.3$ & 0.29 \\
\hline no & 388 & 285 & 73.5 & $72.9-74.0$ & \\
\hline
\end{tabular}

\section{Number of}

people per

household

\begin{tabular}{lrrrrr}
\multicolumn{1}{c}{5} & 635 & 478 & 75.3 & $74.0-75.7$ & 0.32 \\
$>5$ & 864 & 640 & 74.1 & $73.7-74.4$ & \\
\hline $\begin{array}{l}\text { Outside toilet**** } \\
\text { yes }\end{array}$ & 254 & 221 & 83.7 & $83.2-84.2$ & $<0.0001$ \\
no & 1,235 & 897 & 72.6 & $72.3-72.8$ & \\
\hline $\begin{array}{l}\text { Parents' } \\
\text { education***** }\end{array}$ & & & & & \\
yes & 88 & 20 & 22.7 & $20.9-24.4$ & 0.13 \\
no & 162 & 49 & 30.2 & $29.4-31.0$ & \\
\hline
\end{tabular}

History of

clinical hepatitis

$\begin{array}{lrrrrr}\text { yes } & 260 & 244 & 93.8 & 93.5-94.1 & \\ \text { no } & 1,188 & 838 & 70.5 & 70.2-70.8<0.0001\end{array}$

Family history of

hepatitis

\begin{tabular}{llllll} 
yes & 975 & 742 & 76.1 & $75.8-76.4$ & 0.05 \\
no & 483 & 348 & 72.0 & $71.5-72.5$ & \\
\hline
\end{tabular}

HAV: hepatitis A virus, +: number of individuals positive for anti-HAV IgG, 95\% CI: $95 \%$ confidence interval, $p$-value: statistical significance, * chi-square for linear trend, ** wells and rain, **** outside of the household, ***** among those $<5$ years of age. 
In addition, higher total anti-HAV was found to be associated with the presence of outside toilet facilities $(p<0.001)$, previous clinical history of hepatitis $(p<0.001)$ and family history of hepatitis $(p=0.05)$ (Table 1).

After adjustment by means of stratification, the risk of HAV infection remained positively associated with personal and family histories of clinical hepatitis and the presence of an outside toilet facility. On the other hand, we could also detect a significant association with the size of the family (Table 2 ).

\section{TABLE 2}

Unadjusted and age-adjusted associations with the presence of total anti-HAV and social demographic, environmental characteristics and past exposures, Lábrea municipality, Amazonas State, Brazil.

\begin{tabular}{lccccccc}
\hline & \multicolumn{3}{c}{ Unadjusted } & & \multicolumn{3}{c}{ Adjusted } \\
\cline { 2 - 4 } \cline { 6 - 7 } Risk factor & $\mathrm{RR}$ & $95 \% \mathrm{CI}$ & $\mathrm{p}$ & & $\mathrm{RR}$ & $95 \% \mathrm{CI}$ & $\mathrm{p}$ \\
\hline Water supply & 1.08 & $0.95-1.22$ & 0.11 & & 1.03 & $0.92-1.16$ & 0.27 \\
\hline Treated water & 1.02 & $0.95-1.09$ & 0.29 & & 1.01 & $0.95-1.07$ & 0.32 \\
\hline $\begin{array}{l}\text { Number of } \\
\text { people per }\end{array}$ & 1.02 & $0.95-1.07$ & 0.32 & 0.95 & $0.90-0.99$ & 0.03 \\
$\begin{array}{l}\text { household } \\
\text { Parents' }\end{array}$ & & & & & \\
education & 0.75 & $0.47-1.17$ & 0.13 & 0.73 & $0.44-1.18$ & 0.11 \\
\hline Past hepatitis & 1.33 & $1.26-1.39<0.001$ & 1.09 & $1.05-1.18$ & $<0.001$ \\
\hline Family history & 1.05 & $0.98-1.12$ & 0.05 & 1.05 & $0.99-1.11$ & 0.02 \\
\hline Outside toilet & 1.15 & $1.08-1.22<0.001$ & 1.10 & $1.05-1.10$ & $<0.001$ \\
\hline RR: relative risk, $95 \% \mathrm{CI}: 95 \%$ confidence interval, $p$-value: statistical significance.
\end{tabular}

\section{DISCUSSION}

Although the overall prevalence rates in the villages ranged from states of intermediate to high endemicity, no more than $60 \%$ of the whole population under the age of ten had already been infected. Prevalence rates of more than $90 \%$ were detected only in young adults, thus defining this region as one of intermediate endemicity, even under such conditions of poverty.

We concede that we had expected higher rates, since studies published previously had correlated poverty and poor sanitation with regions of high endemicity of HAV infection ${ }^{5131626}$. In addition, papers usually refer to northern Brazil as a very highly endemic region $^{371520}$. A prevalence rate of $93.7 \%$ was described among samples from Acre and the Purus river basin collected almost a decade $\mathrm{ago}^{21}$.

Nevertheless, some epidemiological paradigms relating to HAV infection may be questioned, especially the positive association with rural areas and low income. Recently, a very heterogeneous scenario regarding HAV infection has been demonstrated, with rural areas showing infection rates lower than urban regions ${ }^{1}$. Furthermore, intermediate patterns have been described in isolated poor communities, just as we have described here ${ }^{14}$.

In this specific study, poverty may be defined as economic abuse, but this population is living in circumstances of contact with huge quantities of natural resources from the forest, such as rich soil and plentiful fish. The communities are small but were settled not less than 20 years ago. Their children are culturally protected from environmental adversities through care such as the use of boiled water for food or washing, eat very well cooked food and lack of contact with the outside world for the first years. Differences in infection rates within villages may be due to small unmeasured variations in environmental sanitation and personal care.

The most important characteristic of regions with intermediate HAV infection patterns is the exposure of the population to HAV at older ages with increased morbidity ${ }^{819}$. Considering that these regions are highly endemic for HBV infection, especially among young adults ${ }^{5}$, HAV could be contributing towards occurrences of severe clinical cases during superinfection of adolescents and young adults HBV carriers.

In situations in which there is a substantial risk of HAV infection at older ages, with important clinical outcomes, along with significant presence of $\mathrm{HBV}, \mathrm{HAV}$ vaccination should be considered for inclusion in the immunization program for these specific populations, supported by a surveillance program for acute hepatitis.

Vaccination of programs focusing on adolescents in Catalonia have demonstrated efficiency in reducing the prevalence among all age groups under 60 years of age $e^{8}$. It has also been said that HAV could disappear from isolated communities through small improvements in sanitation and vaccination for susceptible individuals ${ }^{10}$.

Surprisingly, among all of the sociodemographic factors evaluated, only the number of people living in the home, after adjustment, and the presence of an outside toilet facility showed statistical associations with positive tests for total anti-HAV.

Crowded homes are a well-known risk factor for HAV dissemination within families ${ }^{1923}$. Indeed, the next-door and third and fourth houses away from the home of a positive case have been described as presenting increased risk of HAV infection ${ }^{18}$.

It is quite odd to have to explain the presence of outside toilets as a risk factor for hepatitis A, but other studies have shown similar results in northeastern Brazil ${ }^{1}$. We believe that, since the soil is very wet and flooded, the few existing toilets (which are not properly built) actually feed the land and the neighbors' backyards with viruses and parasites, for instance after heavy rain. The properties have no fences and are linked by small bridges used during floods.

Transmission is probably facilitated by lack of sanitation, very wet soil and the climate. Nevertheless, individuals seem to be culturally protected until adolescence, when they have to start to challenge the forest and river for survival.

The possibility of change in HAV distribution patterns may be a matter for discussion, since prevalence rates of over $90 \%$ were described for this region, in a cohort of children aged up to 10 years, a decade $\mathrm{ago}^{21}$. Changes in epidemiological patterns are being described everywhere in developing countries $^{49161722}$, particularly within high social classes and in rural areas ${ }^{2}$.

We believe that this question will be addressed a few years from now, since we have been studying a specific population. The 
previous data was, in fact, based on a non-probabilistic sample of only 22 individuals up to the age of 10 years $^{21}$, and social programs had just been implemented.

\section{ACKNOWLEDGEMENTS}

We would like to express our gratitude to the Municipality of Lábrea, through its mayor Gean Barros, and to the people of the villages we visited, for their very warm welcome and willingness to participate in this study. We are also grateful to Dr. Luiz Tadeu Figueiredo, for his peer review of this paper.

\section{REFERENCES}

1. Almeida D, Tavares-Neto J, Queiroz-Andrade M, Dias C, Ribeiro T, Silva-Araújo J, Tatsch F, Paraná R. Aspectos sociodemográficos da soroprevalência de marcadores do vírus da hepatite A no povoado de Cavunge, região do semiárido do Estado da Bahia. Revista da Sociedade Brasileira de Medicina Tropical 39:76-78, 2006.

2. Arankalle VA, Chadha S, Chitambar SD, Walimbe AM, Chobe LP, Gandhe SS. Changing epidemiology of hepatitis A and hepatitis E in urban and rural India (1982-98). Journal of Viral Hepatology 8:293-303, 2001.

3. Assis SB, Souto FDS, Fontes CJF, Gaspar AM. Prevalência da infecção pelos vírus das hepatites A e E em escolares do município da Amazônia Mato-grossense, Brasil. Revista da Sociedade Brasileira de Medicina Tropical 35:155-158, 2002

4. Barzaga BN. Hepatitis A shifting epidemiology in South-East Asia and China. Vaccine 18:S61-S64, 2000.

5. Braga WSM, Brasil LM, Souza RAB, Melo MS, Rosas MDG, Castilho MC, Fonseca JCF. Prevalência da infecção pelos vírus das hepatites B e Delta em Lábrea, rio Purus, Estado do Amazonas. Epidemiologia e Serviços de Saúde 13:35-46, 2004.

6. Centers for Diesease Control and Prevention. Epi Info ${ }^{\mathrm{TM}}$ statistical software, version 3.3.2, Atlanta GA, 2005.

7. Clemens SAC, Fonseca JC, Azevedo T, Cavalcanti A, Silveira TR, Castilho MC, Clemens R. Soroprevalência para hepatite A e B em quatro centros no Brasil. Revista da Sociedade Brasileira de Medicina Tropical 33:1-10, 2000.

8. Dominguez A, Salleras L, Carmona G, Batalla J. Effectiveness of a mass hepatitis A vaccination program in preadolescents. Vaccine 21:698-701, 2003.

9. Fix AD, Martin OS, Gallicchio L, Vial PA, Lagos R. Age-specific prevalence of antibodies to hepatitis A in Santigo, Chile: risk factors and shift in age of infection among children and young adults. American Journal of Tropical Medicine and Hygiene 66:628-632, 2002

10. Focaccia R, Conceição OJ, Sette Jr H, Sabino E, Bassit L, Nitrini DR, Lomar AV, Lorenço R, Vieira De Souza F, Kiffer CR, Santos EB, Gonzales MP, Sáez-Alquézar A, Riscal JR, Fischer D. Estimated prevalence of viral hepatitis in he general population of the municipality of São Paulo, measured by a sorologic survey of a stratified randomized and residence based population. Brazilian Journal of Infectious Diseases 2: 269-284, 1998.

11. Forbes A, Williams R. Changing epidemiology and clinical aspects of hepatitis A. British Medical Bulletin 46: 303-318, 1990.

12. Hadler SC. Global impact $\mathrm{f}$ hepatitis A virus infection changing patterns. In Hollinger FB, Lemon SM, Margolis H (eds) Viral hepatitis and liver disease, proceedings of the 1990 International Symposium on Viral Hepatitis and Liver Diseases: contemporary issues and futures prospects, Williams and Wilkins, Baltimore, p.14-20, 1991

13. Instituto Brasileiro de Geografia e Estatística. Brasília. Disponível em< http:// www.ibge.gov.br/cidadesat/default.php>, 2000.

14. Kozlowski AG, Motta-Castro AR, Nascimento LB, Silva AM, Teles SA, Villar LM, Gaspar AM, Martins RM. Prevalence of hepatitis A virus infection in Afro-Brazilian isolated communities in Central Brazil. Memórias do Instituto Oswaldo Cruz 102:121-123, 2007

15. Lafer MM, Moraes-Pinto MI, Weckx LY. Prevalence of antibodies against hepatitis A vírus among the Kuikuro and Kaiabi indians of Xingu National Park, Brazil. Revista do Instituto de Medicina Tropical de São Paulo 49:155-157, 2007.

16. Letaief A, Kaabia N, Gaha R, Bousaadia A, Lazraq F, Trabelsi H, Ghannem H, Jemni L. Age-specific seroprevalence of hepatitis A among school children in central Tunisia. American Journal of Tropical Medicine and Hygiene 73:40-43, 2005.

17. Mall ML, Rai RR, Philip M, Naik G, Parekh P, Bhawnani SC, Olowokure B, Shamanna M, Weil J. Seroepidemiology of hepatitis A infection in India: changing pattern. Indian Journal of Gastroenterology 20:132-135, 2001.

18. Medronho RA, Valencia LIO, Fortes BPMD, Braga RCC, Ribeiro SM. Análise da soroprevalência da hepatite A em crianças de uma região carente de Duque de Caxias, RJ, Brasil. Revista Brasileira de Epidemiologia 6:328-334, 2003.

19. Melnick JL. History and epidemiology of hepatitis A virus. Journal of Infectious Diseases 171:S2-S8, 1995

20. Nunes HM, Soares MC, Silva HM. Infecção pelo vírus da hepatite A em área indígena da Amazônia oriental Brasileira. Revista da Sociedade Brasileira de Medicina Tropical 37:S52-S56, 2004.

21. Paula VS, Arruda ME, Vitral CL, Gaspar AM. Seroprevalence of viral hepatitis in riverine communities from Western Region of the Brazilian Amazon Basin. Memórias do Instituto Oswaldo Cruz 96:1123-1128, 2001.

22. Tanaka J. Hepatitis A shifting epidemiology in Latin America. Vaccine 18: S57-S60, 2000 .

23. Villar LM, Costa MCE, Paula VS, Gaspar AM. Hepatitis A outbreak in a public school in Rio de Janeiro, Brazil. Memórias do Instituto Oswaldo Cruz 97:301305,2002

24. Vitral CL, Gaspar AM, Souto FJ. Epidemiological pattern and mortality rates for hepatitis A in Brazil, 1980-2002 - a review. Memórias do Instituto Oswaldo Cruz 101:119-127, 2006

25. Vitral CL, Gaspar AM, Yoshida CF. Two competitive enzyme immunoassays for the detection of IgG class antibodies to hepatitis A antigen. Revista da Sociedade Brasileira de Medicina Tropical 24:79-85, 1991.

26. Zago-Gomes MP, Stantolin GC, Perazzio S, Aikawa KH, Gonçalves CS, Pereira FE. Prevalence of anti-hepatitis A antibodies in children of different socioeconomic conditions in Vila Velha, ES. Revista da Sociedade Brasileira de Medicina Tropical 38: 285-289, 2005. 